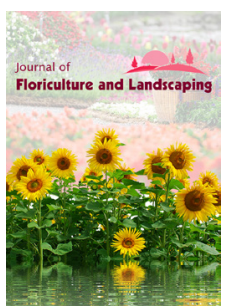

ISSN: $2663-6050$

\title{
Antibacterial effect of Artemisia and ginger extracts in controlling Agrobacterium tumefaciens in roses
}

\author{
Alfred Njagi', Methuselah Mang'erere Nyamwange ${ }^{2}$, \\ Ezekiel Mugendi Njeru', Jonah Kiprono Birgen'
}

'Department of Plant Sciences, Kenyatta University, P. O. Box 43844-00100, Nairobi, Kenya, ${ }^{2}$ Department of
Biochemistry, Microbiology and Biotechnology, Kenyatta University, P. O. Box 43844-00100, Nairobi, Kenya

\begin{abstract}
Rose is the world's most traded cut flowers with $74 \%$ being produced in Kenya. Pests like spider mites, caterpillar, aphids, thrips, nematodes and diseases such as crown gall, downy mildew, powdery mildew and botrytis highly compromise rose production. Crown gall disease caused by Agrobacterium tumefaciens is the most problematic disease of roses in Kenya, causing production loss of up to $60 \%$ depending on the age and variety of rose. An experiment to determine the antibacterial effect of Artemisia and ginger extracts was carried out in vitro, where the inhibitory zones around filter discs soaked with extracts on Muller Hinton agar was established. The extracts were emulsified with dimethylsulfoxide $(50 \%)$ and minimum inhibitory concentrations of Artemisia $(125 \mathrm{mg} / \mathrm{ml})$, ginger $(62.5 \mathrm{mg} / \mathrm{ml})$ and mixture of Artemisia and ginger $(31.25 \mathrm{mg} / \mathrm{ml})$ were used to soak the filter discs whereas the commercial recommended rate of copper hydroxide of $6.25 \mathrm{mg} / \mathrm{ml}$ was used. Artemisia and copper hydroxide (commercial antibiotic) had highest inhibition zone of 12.80 $\mathrm{mm}$ compared to ginger $10.60 \mathrm{~mm}$. Mixture of Artemisia and Ginger had slightly lower inhibition zone $(10.20 \mathrm{~mm})$ though not significantly different from ginger $(\mathrm{P}>0.001)$. An eight-month greenhouse experiment was also done to determine the efficacy of the extracts on inoculated rose plants. The results showed that crown gall incidence and gall weight were low but not significantly different from copper hydroxide and Artemisia. Crop vigor, which was indicated by stem length was highest for Artemisia treatment with an average of $73.54 \mathrm{~cm}$ followed by copper hydroxide $(67.25 \mathrm{~cm})$ while ginger and mixture of ginger and Artemisia had $53.44 \mathrm{~cm}$ and $64.70 \mathrm{~cm}$ respectively. From the results of this research, Artemisia and Ginger extracts are promising alternative to control crown gall and possibly other diseases in field crops. Artemisia performance compares well with copper hydroxide and therefore the best alternative to replace copper hydroxide.
\end{abstract}

*Corresponding Author: Methuselah Mang'erere Nyamwange,

E-mail: nmethu1992@gmail. com

Key words: Roses, Crown gall, Artemisia, ginger, Agrobacterium tumefaciens

\section{INTRODUCTION}

Rose production in Kenya is hampered by diseases such as crown gall disease, caused by Agrobacterium tumefaciens (Furuya et al., 2004). The bacteria are found worldwide and affect species belonging to over ninety-three plant families (Kado, 2002; Rhouma et al., 2006). In Kenya, the first crown gall incidence was noted in 1998 but has currently spread across all rose production regions (Arim, 2011). Crown gall infected flowers show galls, slow growth, stunting, leaves chlorosis and general decreased production (Agrios, 2005). Depending on age and variety of flowers, about $60 \%$ production loss is possible following infestation by Agrobacterium tumefaciens (Arim, 2011).

Currently, there is no effective conventional pesticide for crown gall control. However, dipping the roots and the crown of rose seedlings in a solution containing nonpathogenic Agrobacterium radiobacter bacteria strain 84 before planting offers protection (Kado, 2002; Arim, 2011), though many farmers have reported re-infection, implying that Agrobacterium radiobacter offers short-lived protection. Copper compounds are widely used by farmers as conventional chemicals against crown gall although its usage in disease management is seldom satisfactory owing to pathogen developing resistance, chemical residues and phytotoxicity reported in many plant species (Agrios, 2005).

Breeding for pest and disease resistance in roses has not been explored because varieties grown depend on dynamic customers' tastes and preferences. Moreover, some rose varieties remain in the market for a very short period, making breeding for resistant uneconomical (Arim, 2011). Careful cultural activities, control of chewing insects and nematodes prevent

Copyright: $\odot$ The authors. This article is open access and licensed under the terms of the Creative Commons Attribution License (http://creativecommons.org/licenses/by/4.0/) which permits unrestricted, use, distribution and reproduction in any medium, or format for any purpose, even commercially provided the work is properly cited. Attribution - You must give appropriate credit, provide a link to the license, and indicate if changes were made. 
natural wounds that form the route of infection for the roses (Burr and Otten, 1999). Other methods which have been used for controlling plant pathogenic microorganisms include using synthetic fungicides and bactericides. However, extensive reliance on these chemicals has brought about disease and pests' resistance (Brent and Holloman, 1998). Further, most synthetic chemicals have been forbidden in many countries owing to their toxicity and negative impact on yields and environment, therefore the need to turn to organic chemicals as alternative (Arim, 2011).

In this study, we hypothesized that the antimicrobial effects of Artemisia and ginger extracts control crown gall disease in roses by Agrobacterium tumefaciens. The specific objectives of the study were to (1) to determine whether Artemisia and Ginger extracts inhibit growth of Agrobacterium tumefaciens in vitro; (2) to determine the efficacy of Artemisia and Ginger extracts in management of crown gall disease in the greenhouse.

\section{MATERIALS AND METHODS}

\section{Study Site}

Isolation and characterization of Agrobacterium tumefaciens, extraction of Artemisia and ginger rhizome crude extracts as well as in vitro testing of antibacterial effects on Agrobacterium tumefaciens was carried out at Kenyatta University Microbiology Laboratory, Kiambu County in Kenya. Greenhouse experiments were set up in Gatoka farm (1631 meters above sea level) in Muranga County. The region has two rainfall seasons with annual rainfall of $835 \mathrm{~mm}$ and temperature range of 21 to $35^{\circ} \mathrm{C}$. The soils are predominantly deep loamy, well weathered and very fertile. The main agricultural products from the county include flowers, coffee, fruits, maize, beef and dairy (Ntale and Litondo, 2013).

\section{Isolation and Characterization of Agrobacterium Tumefaciens}

Young actively growing galls from a rose plant were surface sterilized with $3 \%$ sodium hypochlorite and rinsed several times with sterile water. The galls were grinded using sterile mortar and pestle, centrifuged at $70 \mathrm{rpm}$ for 30 minutes. The supernatant was inoculated on Congo red yeast extract mannitol agar which was then incubated at $28^{\circ} \mathrm{C}$ for ten days (Aysan and Sahin, 2003). Red stained bacteria colonies from Congo red yeast extract mannitol agar was inoculated on selective Yeast peptone glucose agar, incubated in dark at $28{ }^{\circ} \mathrm{C}$ for two days and growth analyzed. Gram stain and biochemical tests such as motility, urease, citrate, catalase and Ketolactose enzyme production were performed on isolated colonies.

\section{Extract Preparation and Phytochemical Analyses of Plant Extracts}

Fresh Artemisia leaves were thoroughly washed under running water, air dried for seven days at room temperature and ground into fine powder using a sterile mortar and pestle. Ginger rhizomes, acquired from supermarket were dried in an oven at $40{ }^{\circ} \mathrm{C}$ for 72 hours. The powdered materials were separately soaked in methanol at the ratio of $1: 4$, poured in an air tight plastic and kept in refrigerator at $4{ }^{\circ} \mathrm{C}$ for 48 hours (Agbo et al., 2000). The mixtures were filtered with cheese cloth, followed by Whattman filter paper, concentrated separately to remove methanol using Rotary Evaporator in a vacuum at $40{ }^{\circ} \mathrm{C}$ until $10 \%$ of their original was achieved (Atata et al., 2003; Mariita et al., 2010). The extracts were further concentrated to complete dryness in a water bath and transferred to vials which were kept at $4{ }^{0} \mathrm{C}$ for laboratory uses. Chemical tests to identify the bioactive constituents in the Artemisia and Ginger extracts were carried out using the standard procedures (Trease and Evans, 2012).

\section{Determination of Minimum Inhibitory Concentrations (MICs)}

Minimum Inhibitory Concentration was achieved through broth micro dilution, using a 96- well microtiter plate in accordance with CLSI guidelines (Wayne, 2011). Extracts were initially emulsified in $50 \%$ Dimethylsulfoxide (DMSO) solution. Through serial two-fold dilutions; Ginger, Artemisia and mixture of ginger and Artemisia extracts of concentration $500 \mathrm{mg} / \mathrm{ml}, 250 \mathrm{mg} / \mathrm{ml}, 125 \mathrm{mg} / \mathrm{ml}, 62.5 \mathrm{mg} / \mathrm{ml}, 31.25 \mathrm{mg} / \mathrm{ml}$, $15.6 \mathrm{mg} / \mathrm{ml}, 7.81 \mathrm{mg} / \mathrm{ml}$ and $3.9 \mathrm{mg} / \mathrm{ml}$ were put in different wells. Copper hydroxide was used as a positive control at manufacturers recommended rate of $62.5 \mathrm{mg} / \mathrm{ml}$ whereas DMSO was used as a negative control. The set up was done in triplicate. About $0.5 \mathrm{ml}$ of A. tumefaciens inoculum was dispensed in the wells of micro titer plate containing the extracts and incubated at $37^{\circ} \mathrm{C}$ for 24 hours. Growth of bacteria was examined as a function of turbidity using Varioscan Flash (Kelava and Cavar, 2011).

\section{Assay of Antimicrobial Activity using Disc Diffusion Method}

Two days old A. tumefaciens suspension was swabbed on Petri dishes containing sterilized Muller Hinton Agar. Sterile filter discs were soaked in MIC solutions of Ginger, Artemisia and mixture of Ginger and Artemisia. The extracts impregnated discs were air dried and placed on the agar plates using sterile forceps. The set up was done in triplicate. The plates were maintained for 2 hours at $4{ }^{\circ} \mathrm{C}$ and then incubated for 24 hours at $37{ }^{\circ} \mathrm{C}$. After incubation, the average mean diameters of inhibitory zones formed around each disc were computed in millimeters.

\section{Greenhouse Experimental Design}

The experiment was laid out in a completely randomized design with six treatments and five replicates for each treatment. Seedlings were transplanted into individual buckets of diameter $20 \mathrm{~cm}$ and 4.5litres volume. The buckets contained soil that was sterilized by autoclaving for 15 minutes at $121{ }^{\circ} \mathrm{C}$ at 15 psi to remove soil borne pests and diseases. Treatments with Artemisia extract, Ginger extracts, Mixture of ginger and Artemisia and 
copper hydroxide was done once per week for nine months from January to September, 2016. Two controls, one with plants inoculated with A. tumefaciens and was not treated and the other with non-inoculated plants that as well received no treatments was set up. Irrigation and sprays for other diseases and pests were done as programmed. Records of disease incidence, weights of the galls and length of harvested stems were evaluated at three months interval for ten months.

\section{Inoculation of the Seedlings}

Less than three days old YEMA slant of A.tumefaciens was suspended in $10 \mathrm{ml}$ of sterile distilled water. The suspension was then shaken vigorously to give a suspension of $10^{8} \mathrm{cfu} / \mathrm{ml}$. A sterile steel wire was used to make $3 \mathrm{~mm}$ deep wounds at three locations on the seedling stems where $0.004 \mathrm{ml}$ of A.tumefaciens suspension was inoculated. The wounds were then wrapped with water- soaked cotton wool for one week when successful inoculation was expected to have taken place.

\section{Data Analyses}

The results were subjected to Analysis of Variance (ANOVA) using Minitab software to test the significant difference of plants extracts in bacterial growth inhibition (in vitro). The efficacy of the plant extracts in the greenhouse was tested through analysis of the disease incidence and severity based on weight of the galls and the stem length (Moore, 1997; Masood et al., 2010). Readings of the above parameters was recorded and analyzed for the month of March, May, July and September of the year 2016. Significant means were separated using Tukeys' test.

\section{RESULTS}

\section{Isolation and Morphological Characterization of Agrobacterium Tumefaciens}

The inoculums from the crown galls absorbed Congo Red dye from yeast extract mannitol agar (YEMA). Mannitol in the YEMA was the carbon source while the yeast extract was the nitrogen source and growth factors for Agrobacteria tumefaciens. Magnesium in the medium provided cations required for bacterial growth. The red stained isolates from YEMA, when streaked on yeast peptone glucose agar established as whitishcream, raised-convex with smooth margins. The contaminant colonies from the galls neither absorbed Congo Red dye nor established on peptone glucose agar.

\section{Inhibition Growth of Agrobacterium Tumefaciens In vitro by Artemisia and Ginger Extracts}

Mean inhibition zones of A.tumefaciens around the disc soaked in Artemisia extract and that soaked in copper hydroxide were the same $(12.80 \mathrm{~mm})$. These zones were significantly higher $(\mathrm{P}<0.001)$ than mean zones of inhibition by ginger $(10.60 \mathrm{~mm})$ and the mixture of ginger and Artemisia $(10.20 \mathrm{~mm})$ as shown in Table 1.
Table 1: Zones of inhibition of Agrobacterium tumefaciens in vitro

\begin{tabular}{lc}
\hline Treatment & Mean zone of inhibition \\
\hline Ginger & $10.60(0.67) \mathrm{b}$ \\
Copper hydroxide & $12.80(0.37) \mathrm{a}$ \\
Control (DMSO) & $6.00(0.00) \mathrm{c}$ \\
Ginger +Artemisia & $10.20(0.37) \mathrm{b}$ \\
Artemisia & $12.80(0.37) \mathrm{a}$ \\
\hline
\end{tabular}

The mean standard errors are presented in parentheses. Values followed by the same letter in the same column are not significantly different at $\mathrm{P}<0.05$ (Tukey's HSD test)

\section{Efficacy of Artemisia and Ginger Extracts in Management of Crown Gall Disease in the Greenhouse}

Stems harvested in March from all treatments did not vary in length (Table 2). In May, lengths of stems harvested from artemisia $(79.22 \mathrm{~cm})$ and from uninoculated $(78.41 \mathrm{~cm})$ treatments were significantly $(\mathrm{P}<0.001)$ taller than those from other treatments. In July, the length of stems from artemisia $(77.84 \mathrm{~cm})$ and uninoculated $(78.23 \mathrm{~cm})$ were significantly $(\mathrm{P}<0.001)$ taller than the other treatments. In September, the length of stems from artemisia treatment $(79.44 \mathrm{~cm})$ and uninoculated plant $(77.42 \mathrm{~cm})$ were significantly taller $(\mathrm{P}<0.001)$ than the stems from other treatments as shown in Table 2.

Comparison of gall weights from various treatments showed a significant difference $(\mathrm{P}<0.001)$ in the gall weights as shown in Table 3. The negative control (uninoculated plants) had significantly $(\mathrm{P}<0.001)$ lower gall weights than other treatments. Inoculated plants that were not treated had the highest gall weight of $52.94 \mathrm{~g}$ while the non-inoculated plants had the least gall weight of $0.06 \mathrm{~g}$. The gall weights obtained from Copper hydroxide, artemisia, ginger and mixture of ginger and artemisia were not significantly different (Table 3).

\section{DISCUSSION}

\section{Isolation and Characterization of Agrobacterium Tumefaciens}

Agrobacterium tumefaciens isolates from crushed fresh galls absorbed Congo red dye and showed a well pronounced growth in glucose peptone agar. The isolates were gram negative rods, motile, catalase positive, urease positive, citrate positive and exhibited negative reaction to both indole and hydrogen sulfide tests. These properties were in agreement with those reported by Islam (2010), for physical and biochemical characteristics of A.tumefaciens. Unlike most bacteria, Agrobacterium tumefaciens is known to produce ketolactose enzyme which causes precipitation of cuprous oxide in Benedict's reagent found in lactose broth, differentiating the isolates from Rhizobium species (Aysan and Sahin, 2003).

\section{In vitro and In vivo antibacterial Activity of Ginger and} Artemisia Extracts

All plant extracts produced zones of inhibition greater than $9 \mathrm{~mm}$ against Agrobacterium tumefaciens, hence the extracts 
Table 2: Length of stems harvested $(\mathrm{cm})$ in the greenhouse in different treatments

\begin{tabular}{|c|c|c|c|c|}
\hline Treatment & March & May & July & September \\
\hline Ginger & $47.82(0.52) \mathrm{a}$ & $62.08(0.62) d$ & $55.02(0.43) \mathrm{c}$ & $48.84(0.38) d$ \\
\hline Artemisia & $57.63(0.47) \mathrm{a}$ & $79.22(0.88) a$ & $77.84(0.62) \mathrm{a}$ & $79.45(0.67) \mathrm{a}$ \\
\hline Copper hydroxide & $48.42(0.55) \mathrm{a}$ & $74.09(0.83) b$ & $70.63(0.52) b$ & $75.87(0.49) b$ \\
\hline Ginger + Artemisia & $50.67(0.45) \mathrm{a}$ & $69.45(0.65) c$ & $74.28(0.58) b$ & $64.41(0.42) c$ \\
\hline Inoculated & $47.22(0.48) \mathrm{a}$ & $60.84(0.54) d$ & $54.24(0.38) \mathrm{c}$ & $47.48(0.35) d$ \\
\hline Uninoculated & $59.81(0.49) \mathrm{a}$ & $78.41(0.85) \mathrm{a}$ & $78.23(0.64) a$ & $77.42(0.58) a$ \\
\hline P-value & 0.056 & 0.001 & 0.001 & 0.001 \\
\hline
\end{tabular}

The mean standard errors are presented in parentheses. Values followed by the same letter in the same column are not significantly different at $\mathrm{P}<0.05$ (Tukey's HSD test)

Table 3: Gall weights harvested in the greenhouse in different treatments

\begin{tabular}{lc}
\hline Treatment & Mean gall weight (g) \\
\hline Copper hydroxide & $30.57(1.55) \mathrm{b}$ \\
Ginger + Artemisia & $32.29(1.36) \mathrm{b}$ \\
Ginger & $33.19(1.82) \mathrm{b}$ \\
Artemisia & $32.47(1.39) \mathrm{b}$ \\
Inoculated & $52.94(1.06) \mathrm{a}$ \\
Non-inoculated & $0.06(0.06) \mathrm{a}$ \\
\hline
\end{tabular}

The mean standard errors are presented in parentheses. Values followed by the same letter in the same column are not significantly different at $\mathrm{P}<0.05$ (Tukey's HSD test)

are considered active (Celikel and Kavas, 2008). Both Artemisia and Copper hydroxide had similar antibacterial effect with an inhibition zone of $12.8 \mathrm{~mm}$. The high contents of phenols and flavonoids in artemisia extracts could be responsible for inhibition of growth of A. tumefaciens. Ginger and mixture of ginger and Artemisia also had remarkable activity against A. tumefaciens. This further demonstrates that a mixture of extracts from both ginger and artemisia could be used to control A. tumefaciens infection. Dimethylsulfoxide (negative control) did not have any antibacterial activity. In another work done on A. Absintium in USA, the extracts exhibited zones of $13 \mathrm{~mm}$ which is comparable with the results of this study (Mikicinski, 2012).

The disease severity, which was showed by weight of the galls and harvested stem length was indirectly related to the size of zone of inhibition achieved by the extracts in vitro. As such, the treatment with the biggest zone of inhibition had the least incidence and the treatment with the smallest zone had the highest incidence. The higher the galls weight, the higher the severity of the crown gall. These results were in agreement with work done by Masood (2010). The performance of the mixture of ginger and artemisia was significantly lower than its individual plant extracts, a possibility of antagonism of secondary metabolites during their activity. Crop growth vigor, analyzed through getting the average length of harvested stem also followed the same trend as the gall weights. As such, the higher the gall weight the shorter the stem length and vice versa.

The antibacterial effects noted in vitro and in vivo were attributable to the secondary metabolites in Artemisia annua and Zingiber officinale extracts. Flavonoids, one of the phenolic compounds found in both Artemisia annua and Zingiber officinale extracts has been found to have antimicrobial activity against plant pathogens in vitro (Cowan, 1999). They work by forming antibacterial complexes with extracellular soluble proteins and bacterial cell wall in response to infection (Trease and Evans, 2012; Orhan et al., 2010). If a combination of phenolic compounds is present, like the case in Artemisia annua (flavonoids and tannins), they work synergistically to achieve better antimicrobial activity (Yadav and Agarawala, 2011). Due to this fact, the antibacterial effect of Artemisia annua is better than Zingiber officinale since the latter did not contain tannins.

Tannins act by binding the poline rich protein that interferes with protein synthesis (Sanches et al., 2015). They also affect microbes through enzyme inhibition and substrate deprivation. Alkaloids act by interfering with the impulse transmission, alters the cell membrane while others affect synthesis of functional protein (Creelman and Mullet, 1997). Saponins bind with the cell membrane cholesterol and form complexes that make pores on the cell surface of the pathogen (Gauthier et al., 2009; Melzig et al., 2011).

\section{CONCLUSIONS}

Ginger and Artemisia extracts demonstrated antibacterial effects both in vitro and in vivo, pointing a possibility of replacing synthetic chemicals with effective plant compounds in managing crop diseases and pests. In the greenhouse experiments, the performance of artemisia extract was significantly better than that of ginger and the mixture of ginger and artemisia. The performance of the mixture of ginger and artemisia was lower than its individual plant extracts, demonstrating a possibility of antagonism of the secondary metabolites. The performance of copper hydroxide and that of artemisia extracts were not significantly different signifying the possibility of replacing copper hydroxide with artemisia extracts.

\section{ACKNOWLEDGEMENTS}

The authors wish to express their appreciation to Kenyatta University Microbiology Laboratory staff for the support during setting up of these experiments.

\section{CONFLICT OF INTERESTS}

The authors declare no conflict of interests. 


\section{REFERENCES}

Agbo, K. A., Adediwara, A. A., \& Jaiyesimi, R. P. (2000). Ethnobotanical survey of plants used in the Management of Diabetes Mellitus in Southwestern Region of Nigeria. Journal of Medicine and Medical Science, 2(1), 20-24.

Agrios, G. N. (2005). Plant Pathology, Academic press, New York, 5: 323$326,661,664$.

Arim (2011). The impact of Agrobacterium tumefaciens and other soil borne disease causing agents of economic importance in production of roses. Proceedings of Video Conference on Global Competitiveness of the Flower Industry in the East African region. Kenya Development Learning Centre (KDLC) 07th June 2011.

Atata R.F., Sani A. and Ajewole S.M. (2003). Effect of Stem Bark extracts of Enantia chloranta on some Clinical Isolates. Nigeria Society for Experimental Biology, 15(2), 84-92.

Aysan, Y., \& Sahin, F. (2003). An outbreak of crown gall disease on rose caused by Agrobacterium tumefaciens in Turkey. Plant Pathology, 52, 780-780. https://doi.org/10.1111/j.1365-3059.2003.00889.x

Brent, K. J., \& Holloman, D. W. (1998). Fungicide resistance: The assessment of risk. FRAC, Global Crop Protection Federation, Brussels, Monograph.2:1-48.

Burr, T. J., \& Otten, L. (1999). Crown gall of grape: biology and disease management. Annual Reviews Phytopathology, 37, 53 - 80. https:// doi.org/10.1146/annurev.phyto.37.1.53

Celikel, N., \& Kavas, G. (2008). Bioactivity of beneficial phytochemicals. Food Science, 26, 174-181.

CLSI. (2011). Performance Standards for Antimicrobial Susceptibility Testing, Twenty-First Informational Supplement. CLSI document M100-S21. Clinical and Laboratory Standards Institute, Wayne, Pa, USA, 2011.

Cowan M. M. (1999). Plant products as antimicrobial agents. Clinical Microbiology Reviews, 12(4), 564-582.

Creelman, R. A., \& Mullet, J. E. (1997). Biosynthesis and action of jasmonates in plants. Annual Review of Plant Physiology and Plant Molecular Biology, 48, 355-381. https://doi.org/10.1146/annurev. arplant.48.1.355

Furuya, N., Shimokusuzono, F., Nakamura, Y., Takeshita, K. N. M., Matsuyama, N., \& Takanami, K. M. Y. (2004). Crown gall of tobacco caused by Agrobacterium tumefaciens biovar 1 in tobacco fields. Journal General Plant Pathology, 70, 39-44. https://doi.org/10.1007/ s10327-003-0088-1

Gauthier, C., Legault, J., Girard-Lalancette, K., Mshvildadze, V., \& Pichette, A. (2009). Haemolytic activity, cytotoxicity and membrane cell permeabilization of semi-synthetic and natural lupane- and oleanane-type saponins. Bioorganic \& Medicinal Chemistry, 17(5), 2002-2008. https://doi.org/10.1016/j.bmc.2009.01.022

Islam, M. S., Akter, M. M., Rahman, M. A., Rahman, M. M., Akhtar, M. M., \& Alam M. F. (2010). Isolation of Agrobacterium tume-faciens strains from crown gall sample of dicotylendonous plants in Bangladesh. Current Research Bacteriology, 3(1), 27-36.

Kado, C. I. (2002). Crown gall tumors. Encyclopedia of Genetics. S. Brenner and J. H. Miller, eds. Academic Press, San Diego, CA. 1: 1-3

Kelava, T., \& Cavar, I. (2011). Actions of drug solvents-Biological actions of drug solvents. Periodicum Biologorum, 113(3), 311-320.

Mariita, R. M., Ogol, C. K. P. O., Oguge, N. O., \& Okemo, P. O. (2010). Antitubercular and phytochemical investigation of methanol extracts of medicinal plants used by the Samburu community in Kenya. Tropical Journal of Pharmaceutical Research, 9(4), 379-385.

Masood, A., Saeed, S., Iqbal, N., Malik, M. T., \& Kazmi, M. R. (2010). Methodology for evaluation of symptoms severity of mango sudden death syndrome in Pakistan. Pakistan Journal of Botany, 42(2), 1289-1291.

Melzig, M. F., Bader, G., \& Loose, R. (2001). Investigations of the mechanism of membrane activity of selected triterpenoid saponins. Planta Medica, 67(1), 43-48. https://doi.org/10.1055/s-2001-10632

Mikicinski, A. P., Sobiczewski, P., \& Berczyński, S. (2012). Plants antimicrobial tests. Journal of Plant Protection Research, 52, 4.

Moore, L. W., Kado, C. I., \& Bouzar, H. (1997). Agrobacterium. In Laboratory Guide for Identification of Plant Pathogenic Bacteria, American Phytopathological Society Press, America, 1,16-36.

Ntale, J. F., \& Litondo, K. O. (2013). “Determinants of Commercial Mixed Farming on Small of Agriculture, Kenya.

Orhan, D. D., Zc- elik, B., Zgen, S., \& Ergun, F. (2010). Antibacterial, antifungal and antiviral activities of some flavonoids. Microbiological Research, $65,496-504$.

Rhouma, A., Boubaker, A., Nesme, X., \& Dessaux, Y. (2006). Plasmid and chromosomal diversity of a Tunisian collection of Agrobacterium tumefaciens strains. Tunisian Journal Plant Protection, 1, 73-84.

Sanches, N.R, Cortez, D.A.G., Schiavini, M. S., Nakamura, C. V., \& Filho, B. P. D. (2015). An evaluation of antibacterial activities of Psidium guajava (L.). Brazilian Archives of Biology and Technology, 48(3), 429-436.

Tsuchiya, H., Sato, M., Miyazaki, T., Fujiwara, S., Tanigaki, S., Ohyama, M. Tanaka, T., \& linuma, M. (1996). Comparative study on the antibacterial activity of phytochemical flavanones against methicillin-resistant Staphylococcus aureus. Journal of Ethnopharmacology, 50(1), 27-34. https://doi.org/10.1016/0378-8741(96)85514-0

Yadav, R. N. S., \& Agarawala, M. (2011). Phytochemical analysis of some medicinal plants, Journal of Phytology, 3(12), 10-14. 